\title{
Influence of Calcium and Phosphorus, Lactose, and Salt-to-Moisture Ratio on Cheddar Cheese Quality: Proteolysis During Ripening
}

\author{
P. Upreti, ${ }^{*}$ L. E. Metzger, ${ }^{* 1}$ and K. D. Hayes† \\ *MN-SD Dairy Foods Research Center, Department of Food Science and Nutrition, \\ University of Minnesota, St. Paul 55108 \\ †Department of Food Science, Purdue University, West Lafayette, IN 47906
}

\section{ABSTRACT}

Proteolysis in cheese is influenced by the state of proteins (protein-calcium-phosphate interactions), level of indigenous milk enzymes (plasmin), externally added milk-clotting enzymes (chymosin), and endogenous and exogenous enzymes from starter and nonstarter lactic acid bacteria (NSLAB). The objective of this study was to determine how different levels of calcium $(\mathrm{Ca})$ and phosphorus $(\mathrm{P})$, residual lactose, and salt-to-moisture ratio (S/M) in cheese influence proteolysis during ripening. Eight cheeses with 2 levels of $\mathrm{Ca}$ and $\mathrm{P}(0.67$ and $0.47 \%$ vs. 0.53 and $0.39 \%$, respectively), 2 levels of lactose at pressing $(2.4$ vs. $0.78 \%)$, and 2 levels of S/M (6.4 vs. 4.8\%) were manufactured. The cheeses were analyzed for changes in $\mathrm{pH} 4.6$-soluble $\mathrm{N}$, and starter and NSLAB counts during $48 \mathrm{wk}$ of ripening. Cheeses at $\mathrm{d} 1$ were also analyzed for residual chymosin, plasmin, and plasminogen activity. A significant increase in soluble $\mathrm{N}$ was observed during ripening for all the treatments. Cheeses with low $\mathrm{Ca}$ and $\mathrm{P}$, low lactose, and low S/M treatments exhibited higher levels of proteolysis as compared to their corresponding high treatments. Differences in the rate of proteolysis for cheeses with different levels of $\mathrm{Ca}$ and $\mathrm{P}$ might be due to changes in protein conformation and differences in residual chymosin in the cheeses. Cheeses with low $\mathrm{Ca}$ and $\mathrm{P}$ were manufactured by lowering the $\mathrm{pH}$ at set and drain, which led to higher chymosin retention in cheeses with low $\mathrm{Ca}$ and $\mathrm{P}$ compared with high $\mathrm{Ca}$ and $\mathrm{P}$. Differences in proteolysis between treatments with different levels of lactose were also partly attributed to residual chymosin activity. In all treatments, a major fraction of plasmin existed as plasminogen, indicating minimal contribution of plasmin to proteolysis in Cheddar cheeses. The number of starter bacteria, in all treatments, decreased significantly during ripening. However, the decrease was larger in the case of high $\mathrm{S} / \mathrm{M}$ treatments compared with low $\mathrm{S} / \mathrm{M}$ treatments.

Received August 15, 2005.

Accepted September 26, 2005.

${ }^{1}$ Corresponding author: lmetzger@umn.edu
In contrast, the number of NSLAB increased during ripening, and low $\mathrm{S} / \mathrm{M}$ cheeses had higher counts compared with high S/M cheeses. The differences in proteolysis due to $\mathrm{S} / \mathrm{M}$ were partially attributed to changes in protein conformation or bacterial proteolytic activity.

Key words: proteolysis, chymosin, plasmin, lactic acid bacteria

\section{INTRODUCTION}

Proteolysis during ripening of Cheddar cheese is important for its flavor and texture development. The formation of peptides and free amino acids during ripening contributes to the flavor either directly or by acting as a precursor for other flavor compounds that are formed through transamination, deamination, decarboxylation, desulfuration, and so on (Sousa et al., 2001). In addition, proteolysis contributes to softening of the cheese texture during ripening as a consequence of the breakdown of intact casein into polypeptides and smaller water-soluble peptides that do not contribute to the protein matrix. However, under certain circumstances, proteolysis can lead to formation of bitter peptides that result in undesirable bitterness in Cheddar cheese (Stadhouders, 1962). This warrants a control on the factors that influence proteolysis in Cheddar cheese. The proteolytic process in Cheddar cheese is catalyzed by enzymes from milk (plasmin, cathepsin $\mathrm{D}$, somatic cell proteinases), coagulant (chymosin, pepsin, or other fungal-derived coagulants), starter and nonstarter lactic acid bacteria (NSLAB), or exogenous enzymes added to accelerate ripening (Fox and McSweeney, 1996). We hypothesize that $\mathrm{Ca}$ and $\mathrm{P}$, residual lactose, and salt-tomoisture ratio (S/M) influence proteolysis in Cheddar cheese by influencing one or more of the above mentioned factors.

Calcium and $P$ contribute to casein micellar structure and removal of $\mathrm{Ca}$ and $\mathrm{P}$ from caseins causes disaggregation of casein micelles (Hsu and Shipe, 1986). This disaggregation exposes a larger surface area of proteins to proteinases and leads to an increase in enzymesubstrate interactions. Therefore, cheeses with decreased $\mathrm{Ca}$ and $\mathrm{P}$ exhibit higher proteolysis (Marcos et 
al., 1976; Lawrence et al., 1987). However, studies that investigate the influence of $\mathrm{Ca}$ on proteolysis in cheese generally use modifications in set and drain $\mathrm{pH}$ to obtain cheeses with different levels of $\mathrm{Ca}$. These modifications also control the proportion of residual chymosin in the cheese (Stadhouders, 1962; Holmes et al., 1977). A higher level of chymosin will obviously increase the rate of proteolysis. In addition, Lawrence et al. (1987) proposed that $\mathrm{pH}$ at draining influences plasmin retention in cheese. However, Farkye and Fox (1990) did not observe any influence of drain $\mathrm{pH}$ on residual plasmin activity in cheese.

Relatively few studies have reported the influence of lactose content of cheeses on proteolysis during ripening. Residual lactose content influences the extent of acid production in cheese and should influence bacterial growth and $\mathrm{pH}$-dependent activity of enzymes. ShakeelUr-Rehman et al. (2004) demonstrated that cheeses with higher lactose had lower total amino acids concentration after $180 \mathrm{~d}$ of ripening. Peichevski and Petrova (1979) reported that washing of cheese curds using water up to $20 \%$ before scalding and after cutting increased the biochemical processes in Vitosha cheese. An increase in proteolysis in washed curd cheeses was also observed by Stadhouders (1962), who attributed it to a higher retention of chymosin in these cheeses.

The S/M of cheese markedly influences its rate of proteolysis (Marcos et al., 1976; Thomas and Pearce, 1981; Lane and Fox, 1999). A lower S/M increases proteolysis of $\alpha_{\mathrm{S}^{-}}$and $\beta$-casein (Thomas and Pearce, 1981; Schroeder et al., 1988; Lane and Fox, 1999). Grufferty and Fox (1988) found that the addition of $\mathrm{NaCl}$ to milk caused a release of plasmin from casein micelles. Therefore, a higher rate of salting may lower plasmin retention in cheese, and should decrease the extent or rate of proteolysis. In addition, S/M influences water activity $\left(\mathbf{a}_{\mathbf{w}}\right)$ of cheese (Marcos et al., 1981) and therefore influences growth and protein metabolism of starter or NSLAB (Dawson and Feagan, 1957). The $\mathrm{a}_{\mathrm{w}}$ of cheese can also modify the activity of other proteolytic enzymes present in cheese.

Although the above mentioned studies investigated the influence of one or more factors on proteolysis in cheese or model systems, no study, to our knowledge, has examined influence of all the 3 factors in unison. The objective of this study was to investigate the concomitant influence of $\mathrm{Ca}$ and $\mathrm{P}$, residual lactose, and $\mathrm{S} / \mathrm{M}$ on proteolysis in Cheddar cheese through its influence on indigenous milk enzymes (plasmin) and externally added milk-clotting enzymes (chymosin), and number of live starter and NSLAB.

\section{MATERIALS AND METHODS \\ Experimental Design}

Three replicates of Cheddar cheeses with 2 levels (high and low) of $\mathrm{Ca}$ and $\mathrm{P}$, residual lactose, and salt- to-moisture ratio $(\mathrm{S} / \mathrm{M})$ were manufactured. The 8 different treatments were high $\mathrm{Ca}$ and $\mathrm{P}-$ high lactosehigh S/M (HHH); high Ca and P-high lactose-low S/ M (HHL); high Ca and P-low lactose-high S/M (HLH); high $\mathrm{Ca}$ and $\mathrm{P}-$ low lactose-low S/M (HLL); low Ca and P-high lactose-high S/M (LHH); low $\mathrm{Ca}$ and P-high lactose-low S/M (LHL); low Ca and P-low lactose-high S/M (LLH); and low Ca and P-low lactose-low S/M (LLL). A detailed description of cheese manufacturing protocols followed to obtain the desired cheese composition is discussed in a companion article (Upreti and Metzger, 2006). Average chemical composition of the 8 cheeses is shown in Table 1 . The cheeses were ripened for $48 \mathrm{wk}$, and changes in starter and NSLAB counts, and $\mathrm{pH} 4.6$-soluble $\mathrm{N}$ were monitored during ripening. Cheeses at $\mathrm{d} 1$ were also analyzed for residual activity of chymosin, plasmin, and plasminogen.

\section{Proteolysis in Cheeses During Ripening}

In our study, we have characterized proteolysis by measuring $\mathrm{pH} 4.6$-soluble $\mathrm{N}$ and results have been reported as soluble $\mathrm{N}$ (as a percentage of total $\mathrm{N}$ ). The $\mathrm{pH}$ 4.6-soluble $\mathrm{N}$ is an index of proteolysis, and measures the amount of casein that has been hydrolyzed and cannot be precipitated at $\mathrm{pH} 4.6$ as per the definition of caseins (Sousa et al., 2001). The $\mathrm{pH} 4.6$-soluble $\mathrm{N}$ in cheeses was measured at $\mathrm{d} 1$, and wk $2,4,8$, 16,32 , and 48 by using a Dumas-based rapid method (Lehtola and Metzger, 2004), with slight modifications. In this method, approximately $0.17 \mathrm{~g}$ of cheese was weighed in a 1.5-mL microcentrifuge tube (Fisher Scientific, Fairlawn, NJ), and mixed with $1 \mathrm{~mL}$ of $\mathrm{pH} 4.6$ Sharp's solution (Bynum and Barbano, 1985). The cheese was thoroughly dispersed in the buffer solution using a bead-blaster (Mini-Beadbeater, Biospec Products, Bartlesville, OK) at 5,000 rpm for $2 \mathrm{~min}$. The cheese/buffer mixture was then left undisturbed for 30 min at room temperature. The mixture was centrifuged for $10 \mathrm{~min}$ using a single-speed (15,000 rpm) Microfuge E centrifuge (Beckman Instruments, Inc., Palo Alto, CA). The separated fat layer at the top was removed using a spatula, and discarded. The fat adhering to the walls of the microcentrifuge tubes was also removed using a cotton tip (PSS Select cotton-tipped applicator, Jacksonville, FL). The supernatant was discarded and an additional $1 \mathrm{~mL}$ of Sharp's solution was added to the pellet. The pellet was again thoroughly dispersed in the solution using the bead-blaster at 5,000 rpm for $1 \mathrm{~min}$. The solution was subsequently left undisturbed for $30 \mathrm{~min}$ at room temperature. The mixture was again centrifuged at 15,000 rpm for $10 \mathrm{~min}$, and residual fat was removed and the supernatant was discarded. The whole pellet was transferred to a tin foil cup (Leco Cor- 
UPRETI ET AL.

Table 1. Average chemical composition of cheeses expressed as percentage by weight of cheese (mean of 3 replicates)

\begin{tabular}{lcccccccc}
\hline & \multicolumn{7}{c}{ Treatment $^{1}$} \\
\cline { 2 - 8 } & HHH & HHL & HLH & HLL & LHH & LHL & LLH & LLL \\
\hline Moisture & $32.07^{\mathrm{a}}$ & $33.80^{\mathrm{bc}}$ & $33.07^{\mathrm{ab}}$ & $35.21^{\mathrm{de}}$ & $34.08^{\mathrm{bcd}}$ & $35.94^{\mathrm{e}}$ & $34.39^{\mathrm{cd}}$ & $37.57^{\mathrm{f}}$ \\
Fat & $35.93^{\mathrm{a}}$ & $34.95^{\mathrm{ab}}$ & $35.66^{\mathrm{ab}}$ & $34.75^{\mathrm{abc}}$ & $34.48^{\mathrm{bcd}}$ & $33.62^{\mathrm{cd}}$ & $34.67^{\mathrm{abc}}$ & $33.32^{\mathrm{d}}$ \\
Protein & $26.40^{\mathrm{a}}$ & $25.55^{\mathrm{abc}}$ & $26.02^{\mathrm{ab}}$ & $25.29^{\mathrm{bcd}}$ & $25.15^{\mathrm{cd}}$ & $24.77^{\mathrm{cd}}$ & $25.29^{\mathrm{bcd}}$ & $24.46^{\mathrm{d}}$ \\
Salt & $2.04^{\mathrm{bc}}$ & $1.68^{\mathrm{d}}$ & $2.14^{\mathrm{ab}}$ & $1.73^{\mathrm{cd}}$ & $2.28^{\mathrm{ab}}$ & $1.63^{\mathrm{d}}$ & $2.47^{\mathrm{a}}$ & $1.75^{\mathrm{cd}}$ \\
Salt-to-moisture ratio & $6.37^{\mathrm{a}}$ & $4.98^{\mathrm{b}}$ & $6.48^{\mathrm{a}}$ & $4.92^{\mathrm{b}}$ & $6.71^{\mathrm{a}}$ & $4.53^{\mathrm{b}}$ & $7.17^{\mathrm{a}}$ & $4.65^{\mathrm{b}}$ \\
Lactose (d 1) & $1.52^{\mathrm{a}}$ & $1.35^{\mathrm{c}}$ & $0.32^{\mathrm{de}}$ & $0.11^{\mathrm{e}}$ & $1.64^{\mathrm{ab}}$ & $1.41^{\mathrm{bc}}$ & $0.49^{\mathrm{d}}$ & $0.27^{\mathrm{e}}$ \\
Total Ca & $0.69^{\mathrm{a}}$ & $0.68^{\mathrm{a}}$ & $0.67^{\mathrm{a}}$ & $0.66^{\mathrm{a}}$ & $0.55^{\mathrm{b}}$ & $0.54^{\mathrm{b}}$ & $0.55^{\mathrm{b}}$ & $0.51^{\mathrm{b}}$ \\
Total P & $0.48^{\mathrm{a}}$ & $0.48^{\mathrm{a}}$ & $0.48^{\mathrm{a}}$ & $0.47^{\mathrm{a}}$ & $0.42^{\mathrm{b}}$ & $0.42^{\mathrm{b}}$ & $0.41^{\mathrm{b}}$ & $0.40^{\mathrm{b}}$ \\
\hline
\end{tabular}

${ }^{\mathrm{a}-\mathrm{f}}$ Means in a row with a common superscript do not differ $(P \geq 0.05)$.

${ }^{1}$ Treatments: $\mathrm{HHH}=$ high $\mathrm{Ca}$ and $\mathrm{P}$, high lactose, and high salt-to-moisture $(\mathrm{S} / \mathrm{M}) ; \mathrm{HHL}=$ high Ca and $\mathrm{P}$, high lactose, and low S/M; HLH = high Ca and P, low lactose, and high S/M; HLL = high Ca and P, low lactose, and low S/M; LHH = low Ca and P, high lactose, and high S/M; LHL = low Ca and P, high lactose, and low S/M; LLH = low Ca and P, low lactose, and high S/M; LLL = low Ca and P, low lactose, and low $\mathrm{S} / \mathrm{M}$.

poration, St. Joseph, MI), and weighed. The tin foil containing the pellet was used for measuring total $\mathrm{N}$ using the Dumas combustion method (Leco Tru Spec $\mathrm{N}$ analyzer, Leco, St. Joseph, MI; Wiles et al., 1998). The $\mathrm{pH} 4.6$-soluble $\mathrm{N}$ content in the cheese was calculated using the following equation:

$\mathrm{pH} 4.6$ soluble $\mathrm{N}=$

$\frac{\left\{\text { Total } \mathrm{N} \text { in cheese }-\left[\frac{\% \mathrm{~N} \text { in pellet }}{100} \times \text { Weight of pellet }\right]\right\}}{\text { Weight of cheese sample }} \times 100$

\section{Microbiological Analyses}

Starter bacteria and NSLAB counts were measured in cheese curds before salting, and cheeses at $\mathrm{d} 1$, and wk 4, 8, 16, 32, and 48. Starter count was analyzed using Bacto-Elliker agar (Difco Elliker broth, Becton, Dickinson and Company, Sparks, MD) and NSLAB using LBS agar (adjusted to $\mathrm{pH} 5.4$ using glacial acetic acid). A 10-g sample of cheese was homogenized with $90 \mathrm{~mL}$ of $2 \%$ trisodium citrate buffer for 2 min using a stomacher (Colworth Stomacher 400, AJ Seward, London, UK) at room temperature. Serial dilutions were prepared using $2 \%$ sodium citrate buffer and samples were inoculated into sterile disposable Petri plates and pour-plated with respective media. The plates were then incubated at $32^{\circ} \mathrm{C}$ for $48 \mathrm{~h}$, under aerobic conditions for starter bacteria; and anaerobically (BBL GasPak Anaerobic System; Becton, Dickinson) for NSLAB. In addition, cheeses were analyzed to identify the type of lactococci present; that is, Lactococcus lactis ssp. lactis vs. Lactococcus lactis ssp. cremoris. To identify the presence of cremoris vs. lactis, the cheese dilutions were plated on Bacto-Elliker agar, and incubated at different temperatures $\left(30\right.$ and $\left.40^{\circ} \mathrm{C}\right)$. The presence of similar number of colonies of starter bacteria in the plates incubated at 30 and $40^{\circ} \mathrm{C}$ indicated that the starter bacteria used was primarily L. lactis ssp. lactis, which can grow at both temperatures (Sandine et al., 1972). The possibility of contamination of these plates with NSLAB (lactobacilli) was checked by morphological (cocci vs. rods) examination of cells from the various colonies using a microscope.

\section{Residual Chymosin Activity}

Residual chymosin activity in cheeses at $d 1$ was determined by using a method similar to that of Hurley et al. (1999). In this procedure, approximately $1 \mathrm{~g}$ of cheese was homogenized with $20 \mathrm{~mL}$ of $0.1 M$ trisodium citrate using a high-shear Omni mixer-homogenizer (model 17105, Omni International, Waterbury, CT). About $210 \mu \mathrm{L}$ of cheese homogenate was transferred to a 1.5-mL microcentrifuge tube (Fisher Scientific), and mixed with $90 \mu \mathrm{L}$ of $1 \mathrm{mg} / \mathrm{mL}$ aqueous solution of synthetic heptapeptide substrate (Pro-Thr-Glu-Phe-[ $\mathrm{NO}_{2}-$ Phe]-Arg-Leu, Bachem Bioscience Inc., King of Prussia, PA). To this mixture, $600 \mu \mathrm{L}$ of $100 \mathrm{mM}$ sodium formate buffer (containing $0.05 \%$ sodium azide, adjusted to $\mathrm{pH}$ 3.2) was also added. The microcentrifuge tubes were then incubated at $37^{\circ} \mathrm{C}$ for $24 \mathrm{~h}$. The reaction was terminated by heating the tubes at $70^{\circ} \mathrm{C}$ for 10 min using a heating block (Temp-Blok Equatherm, Laboratory-Line Instruments, Inc., Melrose Park, IL). The tubes were then centrifuged (Biofuge 15, Heraeus Sepatech GmbH, West Germany) at $16,000 \times g$ for $10 \mathrm{~min}$ to remove the precipitated proteins and other insoluble matter. The supernatant was filtered through $0.22-\mu \mathrm{m}$ syringe filters (Millex-GV, Millipore Corporation, Bedford, MA) and $175 \mu \mathrm{L}$ of the filtrate was injected into the HPLC. 
Table 2. Mean squares and probabilities (in parentheses) of differences in chymosin, plasmin, and plasminogen in cheeses at $d$

\begin{tabular}{|c|c|c|c|c|}
\hline Factors & df & Chymosin & Plasmin & Plasminogen \\
\hline $\mathrm{Ca}$ and $\mathrm{P}$ & 1 & $\underset{(<0.01)}{0.1204 *}$ & $\underset{(<0.01)}{3.68 \times 10^{-11 *}}$ & $\underset{(<0.01)}{1.35 \times 10^{-8 *}}$ \\
\hline Lactose & 1 & $\begin{array}{l}0.0017 \\
(0.10)\end{array}$ & $\begin{array}{l}1.20 \times 10^{-11} \\
(0.06)\end{array}$ & $\begin{array}{l}2.20 \times 10^{-9} \\
(0.25)\end{array}$ \\
\hline $\mathrm{S} / \mathrm{M}$ & 1 & $\begin{array}{l}0.0002 \\
(0.61)\end{array}$ & $\begin{array}{l}3.09 \times 10^{-12} \\
(0.32)\end{array}$ & $\begin{array}{l}4.17 \times 10^{-12} \\
(0.96)\end{array}$ \\
\hline$(\mathrm{Ca}$ and $\mathrm{P}) \times$ Lactose & 1 & $\begin{array}{l}0.0004 \\
(0.40)\end{array}$ & $\begin{array}{l}7.91 \times 10^{-13} \\
(0.61)\end{array}$ & $\begin{array}{l}3.50 \times 10^{-9} \\
(0.16)\end{array}$ \\
\hline Lactose $\times \mathrm{S} / \mathrm{M}$ & 1 & $\begin{array}{l}0.0008 \\
(0.24)\end{array}$ & $\begin{array}{l}1.82 \times 10^{-11} \\
(0.61)\end{array}$ & $\begin{array}{l}5.10 \times 10^{-9} \\
(0.09)\end{array}$ \\
\hline$(\mathrm{Ca}$ and $\mathrm{P}) \times \mathrm{S} / \mathrm{M}$ & 1 & $\begin{array}{l}0.0011 \\
(0.18)\end{array}$ & $\begin{array}{l}1.19 \times 10^{-13} \\
(0.84)\end{array}$ & $\begin{array}{l}3.75 \times 10^{-11} \\
(0.88)\end{array}$ \\
\hline$(\mathrm{Ca}$ and $\mathrm{P}) \times$ Lactose $\times \mathrm{S} / \mathrm{M}$ & 1 & $\begin{array}{l}0.0011 \\
(0.18)\end{array}$ & $\begin{array}{l}5.30 \times 10^{-13} \\
(0.67)\end{array}$ & $\begin{array}{l}2.60 \times 10^{-9} \\
(0.22)\end{array}$ \\
\hline Error & 16 & 0.0087 & $2.87 \times 10^{-12}$ & $1.58 \times 10^{-9}$ \\
\hline
\end{tabular}

*Statistically significant $(P<0.05)$.

The conditions for HPLC analysis were similar to those suggested by Hurley et al. (1999).

Peak areas of the product were used for quantifying the residual activity of chymosin in the cheeses. Results for chymosin activity were expressed in terms of International Milk Clotting Units (IMCU) per gram using a standard curve. The standard curve was prepared using appropriate dilutions of double-strength chymosin (Chy-max, Chr. Hansen, Inc., Milwaukee, WI), which had an activity of $976 \mathrm{IMCU} / \mathrm{mL}$.

\section{Residual Plasmin and Plasminogen Activity}

Residual plasmin and plasminogen activity in cheeses at $\mathrm{d} 1$ were measured using a method described by Fajardo-Lira et al. (2000).

\section{Statistical Analyses}

A $2 \times 2 \times 2$ factorial model with 3 replications was used for statistical analysis (Table 2). Changes in starter and NSLAB counts, and $\mathrm{pH} 4.6$ soluble $\mathrm{N}$ during ripening were analyzed using a repeated measures design. The PROC GLM procedure of SAS, which involved 3 factors (Ca and $\mathrm{P}$, residual lactose, and $\mathrm{S} / \mathrm{M}$ ) as class variables, was used for the data analyses (SAS Institute, 1990).

\section{RESULTS AND DISCUSSION}

\section{Residual Chymosin Activity}

Residual chymosin activity at $\mathrm{d} 1$ was significantly $(P<0.05)$ affected by $\mathrm{Ca}$ and $\mathrm{P}$ (Table 2$)$. Cheeses with high $\mathrm{Ca}$ and $\mathrm{P}$ had a mean residual chymosin activity of $0.26 \mathrm{IMCU} / \mathrm{g}$, which corresponded to about $26 \%$ of the total chymosin added to the milk during cheese manufacture (Table 3 ). In contrast, cheeses with low $\mathrm{Ca}$ and $\mathrm{P}$ had a residual chymosin activity of $0.40 \mathrm{IMCU} / \mathrm{g}$ that corresponded to about $41 \%$ of the total chymosin added to the milk during cheese manufacture (Table 3). Previous researchers have reported that about 6 to $7 \%$ of the chymosin added to the milk is retained in the curd (Holmes et al., 1977). These differences in absolute values of chymosin retention can be attributed to use of different analytical methods to quantify residual chymosin. Our results, however, are similar to those of Nelson (2005), who used a similar method for analyzing cheeses for residual chymosin activity.

The differences in residual chymosin activity between high vs. low $\mathrm{Ca}$ and $\mathrm{P}$ treatments can be attributed to the modifications in set and drain $\mathrm{pH}$ that were used to obtain cheeses with different $\mathrm{Ca}$ and $\mathrm{P}$ content. Cheeses with low $\mathrm{Ca}$ and $\mathrm{P}$ had a lower set and drain $\mathrm{pH}(6.2$

Table 3. Average residual chymosin, plasmin, and plasminogen content in cheese at $d 1$ (mean of 3 replicates)

\begin{tabular}{llll}
\hline Treatment $^{1}$ & $\begin{array}{l}\text { Chymosin } \\
(\mathrm{IMCU} / \mathrm{g})\end{array}$ & $\begin{array}{l}\text { Plasmin } \\
(\mu \mathrm{g} / \mathrm{mg})\end{array}$ & $\begin{array}{l}\text { Plasminogen } \\
(\mu \mathrm{g} / \mathrm{mg})\end{array}$ \\
\hline HHH & 0.24 & 0.012 & 0.35 \\
HHL & 0.25 & 0.009 & 0.28 \\
HLH & 0.29 & 0.012 & 0.20 \\
HLL & 0.25 & 0.013 & 0.28 \\
LHH & 0.39 & 0.010 & 0.21 \\
LHL & 0.40 & 0.007 & 0.21 \\
LLH & 0.39 & 0.009 & 0.22 \\
LLL & 0.41 & 0.010 & 0.22 \\
\hline
\end{tabular}

${ }^{1}$ Treatments: $\mathrm{HHH}=$ high $\mathrm{Ca}$ and $\mathrm{P}$, high lactose, and high saltto-moisture (S/M); HHL = high $\mathrm{Ca}$ and $\mathrm{P}$, high lactose, and low $\mathrm{S} /$ $\mathrm{M} ; \mathrm{HLH}=$ high Ca and $\mathrm{P}$, low lactose, and high $\mathrm{S} / \mathrm{M}$; HLL = high $\mathrm{Ca}$ and $\mathrm{P}$, low lactose, and low $\mathrm{S} / \mathrm{M} ; \mathrm{LHH}=$ low $\mathrm{Ca}$ and $\mathrm{P}$, high lactose, and high S/M; LHL = low $\mathrm{Ca}$ and $\mathrm{P}$, high lactose, and low $\mathrm{S} / \mathrm{M} ; \mathrm{LLH}=$ low $\mathrm{Ca}$ and $\mathrm{P}$, low lactose, and high $\mathrm{S} / \mathrm{M} ; \mathrm{LLL}=$ low $\mathrm{Ca}$ and $\mathrm{P}$, low lactose, and low $\mathrm{S} / \mathrm{M}$. 
and 5.7, respectively), compared with cheeses with high $\mathrm{Ca}$ and $\mathrm{P}$ (6.6 and 6.4, respectively), and hence had higher chymosin associated with the cheese curds. A similar effect of $\mathrm{pH}$ on partitioning of chymosin between the curd and whey has been observed by other researchers (Stadhouders, 1962; Holmes et al., 1977; Lawrence et al., 1987). Holmes et al. (1977) observed that at $\mathrm{pH}$ $6.6,31 \%$ of the rennet activity was in the curd and $72 \%$ in the whey, whereas at $\mathrm{pH} 5.2,86 \%$ of the rennet activity was in the curd and $17 \%$ in the whey.

\section{Residual Plasmin and Plasminogen Activity}

The plasmin content of the cheeses was significantly $(P<0.05)$ influenced by $\mathrm{Ca}$ and $\mathrm{P}$; and marginally $(P=$ 0.06 ) by lactose (Table 2 ). Mean plasmin content in our cheeses ranged from 0.007 to $0.013 \mu \mathrm{g} / \mathrm{mg}$ of cheese (Table 3), with higher plasmin concentration in the high $\mathrm{Ca}$ and $\mathrm{P}$ treatments than in the low $\mathrm{Ca}$ and $\mathrm{P}$ treatments. The plasminogen content of the cheeses was also significantly $(P<0.05)$ influenced by $\mathrm{Ca}$ and $\mathrm{P}$; with high $\mathrm{Ca}$ and $\mathrm{P}$ treatments having higher plasminogen concentration as compared with the low $\mathrm{Ca}$ and $\mathrm{P}$ treatments. The mean plasminogen content of the cheeses ranged from 0.21 to $0.35 \mu \mathrm{g} / \mathrm{mg}$ of cheese (Table 3 ).

The differences in residual plasmin and plasminogen content between high vs. low $\mathrm{Ca}$ and $\mathrm{P}$ treatments can be attributed to the higher set and drain $\mathrm{pH}$ used in the high $\mathrm{Ca}$ and $\mathrm{P}$ treatments. The influence of drain $\mathrm{pH}$ on plasmin retention has also been suggested by Lawrence et al. (1987). They proposed that the higher plasmin activity in Swiss-type cheeses, compared with Cheddar cheeses, is related to the higher drain $\mathrm{pH}$. However, Farkye and Fox (1990) did not observe an effect of drain $\mathrm{pH}$ on plasmin retention in Cheddar cheeses.

Our results show that there is a lower concentration of plasmin compared with plasminogen in the cheeses (Table 3). This could be due to the presence of active inhibitors of plasminogen activators in milk, which were still active in Cheddar cheese. In contrast, manufacture of Swiss or Mozzarella-type cheeses involves extreme heat treatment, which can inactivate inhibitors of plasminogen activators, which increases plasmin activity in Swiss or Mozzarella-type cheeses (Bastian and Brown, 1996).

\section{Starter Counts During Ripening}

Average starter counts were significantly $(P<0.05)$ influenced by $\mathrm{Ca}$ and $\mathrm{P}$ and time, whereas the interaction of time $\times \mathrm{S} / \mathrm{M}$ was marginally $(P=0.06)$ significant (Table 4). As shown in Figure 1, the number of starter bacteria in all treatments decreased during ripening.
However the decrease was slightly larger in the high S/M treatments compared with their low S/M counterparts. Cheeses with high $\mathrm{Ca}$ and $\mathrm{P}$ had lower number of starter bacteria throughout ripening compared with their low $\mathrm{Ca}$ and $\mathrm{P}$ counterparts (HHH vs. LHH, HHL vs. LHL, HLH vs. LLH, and HLL vs. LLL).

The lower starter count in high vs. low $\mathrm{Ca}$ and $\mathrm{P}$ cheeses was surprising, because a higher level of starter inoculum was added during manufacture of high $\mathrm{Ca}$ and $\mathrm{P}$ cheeses compared with low $\mathrm{Ca}$ and $\mathrm{P}$ cheeses (54 vs. $27 \mathrm{~mL} / 100 \mathrm{~kg}$; Upreti and Metzger, 2006). A lower number of starter bacteria in high $\mathrm{Ca}$ and $\mathrm{P}$ cheeses than in low $\mathrm{Ca}$ and $\mathrm{P}$ cheeses could be due to shorter cheese manufacturing time for high $\mathrm{Ca}$ and $\mathrm{P}$ cheeses, although the exact reasons are not known. A decrease in starter counts during ripening is expected due to unfavorable growth conditions in cheese (Dawson and Feagan, 1957; Sandine et al., 1972), and has been observed by others (Dawson and Feagan, 1957; Mistry and Kasperson, 1998; Broadbent et al., 2003). The differences between the high $\mathrm{S} / \mathrm{M}$ and low $\mathrm{S} / \mathrm{M}$ treatments are not surprising because $\mathrm{S} / \mathrm{M}$ directly influences $\mathrm{a}_{\mathrm{w}}$ and ionic strength (Marcos et al., 1981), which are key determinants for growth of lactococci. However, the ability of starter bacteria to survive under the given conditions differs from strain to strain. Strains of Lactococcus lactis ssp. lactis are more salt-tolerant than Lactococcus lactis ssp. cremoris (Dawson and Feagan, 1957; Sandine et al., 1972). Although we identified L. lactis ssp. lactis in our cheeses, our results indicate that its population decreased during ripening even in a cheese with a lower $\mathrm{S} / \mathrm{M}$ of 4.5 . However, a larger decrease of L. lactis ssp. lactis in cheeses with high (i.e., 6.4\%) vs. low (i.e., 4.5\%) S/M indicates its ability to survive in higher numbers at low S/M compared with high S/M. A rapid decrease of starter population in high S/M compared with low S/M cheeses has been observed by other researchers (Schroeder et al., 1988; Mistry and Kasperson, 1998).

Our results indicate that a significant number of starter bacteria $\left(\sim 10^{6} \mathrm{cfu} / \mathrm{g}\right)$ were still present in Cheddar cheese at the end of 48 wk of ripening. Similar levels of viable starter counts have been observed by other researchers (Dawson and Feagan, 1957; Broadbent et al., 2003). The presence of starter bacteria at high levels that are comparable with NSLAB during cheese ripening, even at $48 \mathrm{wk}$, indicates their possible role in influencing cheese characteristics during ripening. Although lysis of dead starter bacterial cells is known to contribute to proteolysis in cheese, the potential contribution from surviving starter bacteria cannot be ignored. 
Table 4. Mean squares and probabilities (in parentheses) of changes in starter and nonstarter lactic acid bacteria (NSLAB) counts, and soluble $\mathrm{N}$ (as \% of total N) in Cheddar cheese during storage at 6 to $8^{\circ} \mathrm{C}$ for 48 wk.

\begin{tabular}{|c|c|c|c|c|}
\hline Factors & df & Starter & NSLAB & $\begin{array}{l}\text { Soluble N } \\
\text { (as \% of total N) }\end{array}$ \\
\hline \multicolumn{5}{|l|}{ Whole plot } \\
\hline $\mathrm{Ca}$ and $\mathrm{P}$ & 1 & $\begin{array}{r}5.14^{*} \\
(<0.01)\end{array}$ & $\begin{array}{l}75.78 \\
(0.08)\end{array}$ & $\begin{array}{c}804.69^{*} \\
(<0.01)\end{array}$ \\
\hline Lactose & 1 & $\begin{array}{c}0.16 \\
(0.61)\end{array}$ & $\begin{array}{l}8.29 \\
(0.54)\end{array}$ & $\begin{array}{l}122.37 * \\
(<0.01)\end{array}$ \\
\hline Salt-to-moisture ratio $(\mathrm{S} / \mathrm{M})$ & 1 & $\begin{array}{l}0.81 \\
(0.25)\end{array}$ & $\begin{array}{l}52.45 \\
(0.13)\end{array}$ & $\begin{array}{c}368.04^{*} \\
(<0.01)\end{array}$ \\
\hline$(\mathrm{Ca}$ and $\mathrm{P}) \times$ Lactose & 1 & $\begin{array}{l}0.30 \\
(0.48)\end{array}$ & $\begin{array}{c}0.35 \\
(0.90)\end{array}$ & $\begin{array}{c}3.65 \\
(0.53)\end{array}$ \\
\hline Lactose $\times \mathrm{S} / \mathrm{M}$ & 1 & $\begin{array}{l}0.55 \\
(0.35)\end{array}$ & $\begin{array}{l}0.13 \\
(0.94)\end{array}$ & $\begin{array}{l}2.74 \\
(0.58)\end{array}$ \\
\hline$(\mathrm{Ca}$ and $\mathrm{P}) \times \mathrm{S} / \mathrm{M}$ & 1 & $\begin{array}{l}1.09 \\
(0.19)\end{array}$ & $\begin{array}{l}3.18 \\
(0.71)\end{array}$ & $\begin{array}{c}4.47 \\
(0.48)\end{array}$ \\
\hline Error & 17 & 0.58 & 21.69 & 8.70 \\
\hline \multicolumn{5}{|l|}{ Subplot } \\
\hline Time & & $\begin{array}{c}649.47^{*} \\
(<0.01)\end{array}$ & $\begin{array}{l}63.03^{*} \\
(<0.01)\end{array}$ & $\begin{array}{c}1747.25^{*} \\
(<0.01)\end{array}$ \\
\hline Time $\times(\mathrm{Ca}$ and $\mathrm{P})$ & 6 & $\begin{array}{c}0.09 \\
(0.89)\end{array}$ & $\begin{array}{l}1.89 \\
(0.28)\end{array}$ & $\begin{array}{r}8.92^{*} \\
(<0.01)\end{array}$ \\
\hline Time $\times$ Lactose & 6 & $\begin{array}{l}0.10 \\
(0.85)\end{array}$ & $\begin{array}{l}1.27 \\
(0.53)\end{array}$ & $\begin{array}{r}9.39 * \\
(<0.01)\end{array}$ \\
\hline Time $\times \mathrm{S} / \mathrm{M}$ & 6 & $\begin{array}{l}0.50 \\
(0.06)\end{array}$ & $\begin{array}{r}7.84^{*} \\
(<0.01)\end{array}$ & $\begin{array}{r}8.03^{*} \\
(<0.01)\end{array}$ \\
\hline Time $\times(\mathrm{Ca}$ and $\mathrm{P}) \times$ Lactose & 6 & $\begin{array}{c}0.04 \\
(0.99)\end{array}$ & $\begin{array}{c}0.57 \\
(0.89)\end{array}$ & $\begin{array}{l}1.92 \\
(0.49)\end{array}$ \\
\hline Time $\times$ Lactose $\times \mathrm{S} / \mathrm{M}$ & 6 & $\begin{array}{c}0.12 \\
(0.80)\end{array}$ & $\begin{array}{c}0.92 \\
(0.72)\end{array}$ & $\begin{array}{l}2.49 \\
(0.33)\end{array}$ \\
\hline Time $\times(\mathrm{Ca}$ and $\mathrm{P}) \times \mathrm{S} / \mathrm{M}$ & 6 & $\begin{array}{c}0.30 \\
(0.29)\end{array}$ & $\begin{array}{l}0.86 \\
(0.75)\end{array}$ & $\begin{array}{l}1.19 \\
(0.76)\end{array}$ \\
\hline Error & 102 & 0.24 & 1.50 & 2.13 \\
\hline
\end{tabular}

*Statistically significant $(P<0.05)$.

\section{NSLAB Counts During Ripening}

Nonstarter lactic acid bacteria counts in cheeses were significantly $(P<0.05)$ affected by time, and the interaction of time $\times \mathrm{S} / \mathrm{M}$; and marginally $(P=0.08)$ influenced by $\mathrm{Ca}$ and $\mathrm{P}$ (Table 4 ). As shown in Figure 1, the number of NSLAB in cheese at the beginning of ripening was low and gradually increased during ripening. The rate of increase of NSLAB population in cheese during ripening was influenced by S/M. As is apparent from Figure 1 , cheeses with low $\mathrm{S} / \mathrm{M}$ showed a larger increase in NSLAB counts compared with their high S/M counterparts (HHH vs. HHL, HLH vs. HLL, LHH vs. LHL, LLH vs. LLL). An increase in the number of NSLAB in Cheddar cheese during ripening is expected because of their ability to grow under cheese ripening conditions (Mistry and Kasperson, 1998; Crow et al., 2001; Broadbent et al., 2003). A larger increase in NSLAB for low S/ $\mathrm{M}$ treatments might be due to a more conducive growth environment in terms of ionic strength and $a_{w}$ in cheeses with low S/M compared with high S/M. A similar effect of salt content on growth of $L$. helveticus was observed by Roy (1991).
As shown in Figure 1, there was substantial variability among the replicates for NSLAB counts. This variation signifies that the occurrence and growth of NSLAB in cheese is largely contributed by the initial bacterial load of milk, and adventitious bacterial contamination of milk during cheese manufacture, yet the growth and selection of NSLAB in cheeses will be influenced by the conditions prevailing in the cheese including its chemical composition. Similar observations have been made by Crow et al. (2001), and a recent study by Broadbent et al. (2003) compared growth of adjunct bacteria in a Cheddar and Colby-type cheese microenvironment. They observed a greater degree of species heterogeneity in Colby cheeses compared with Cheddar cheeses.

\section{Changes in pH 4.6-Soluble $N$ during Ripening}

Changes in $\mathrm{pH} 4.6$-soluble $\mathrm{N}$ in cheeses were significantly $(P<0.05)$ influenced by $\mathrm{Ca}$ and $\mathrm{P}$, residual lactose, $\mathrm{S} / \mathrm{M}$, time, and the interactions of time $\times \mathrm{Ca}$ and $\mathrm{P}$, time $\times$ lactose, and time $\times \mathrm{S} / \mathrm{M}$ (Table 4 ). The level of soluble $\mathrm{N}$ increased in all treatments during ripening, leading to a 3 - to 5 -fold increase in soluble $\mathrm{N}$ by the 

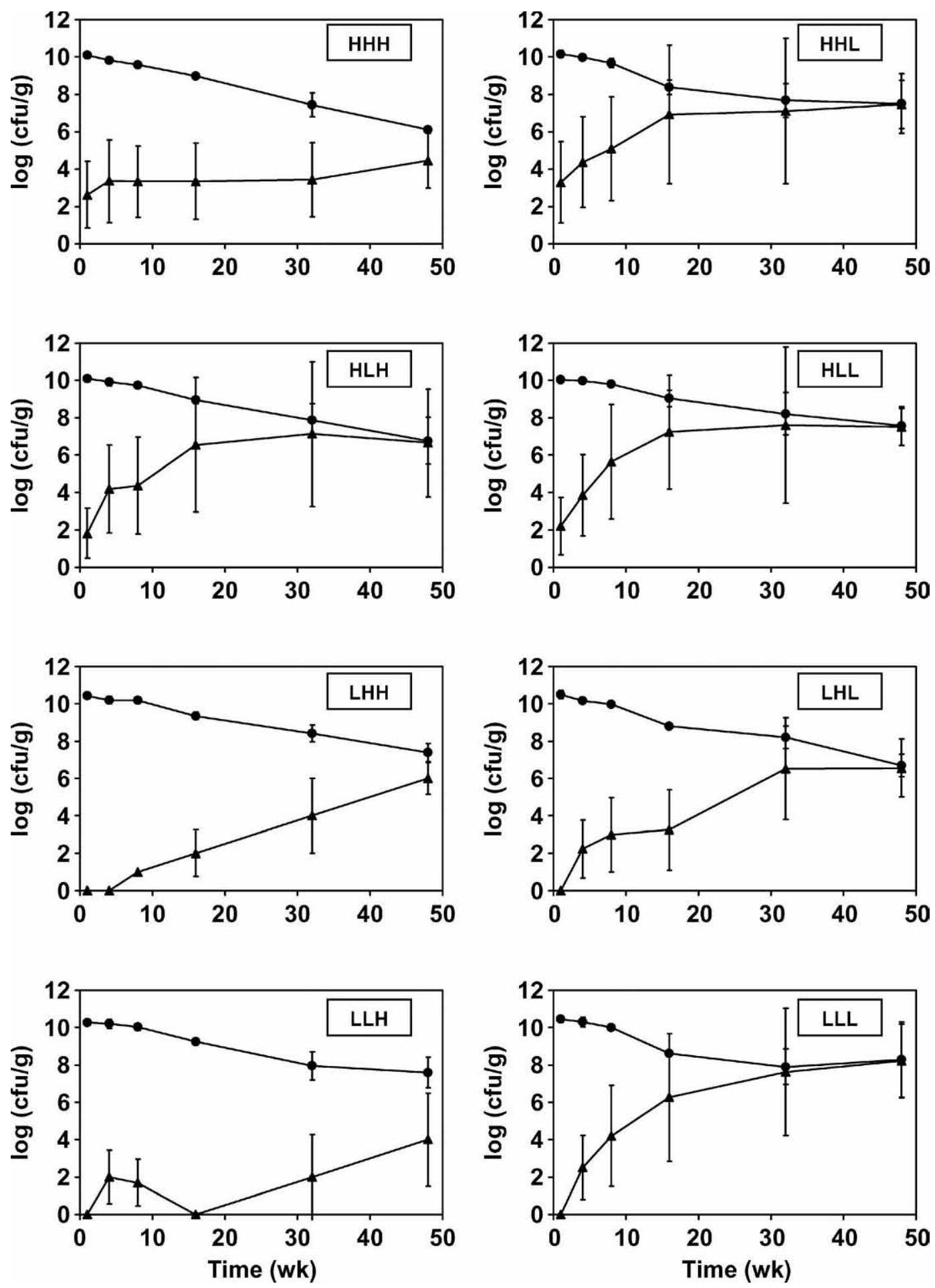

Figure 1. Changes in starter $(\bullet)$ and nonstarter $(\mathbf{\Delta})$ lactic acid bacteria counts during ripening of the 8 cheeses (mean of 3 replicates). Treatments: $\mathrm{HHH}=$ high $\mathrm{Ca}$ and $\mathrm{P}$, high lactose, and high salt-to-moisture (S/M); HHL = high Ca and P, high lactose, and low S/M; HLH = high $\mathrm{Ca}$ and $\mathrm{P}$, low lactose, and high $\mathrm{S} / \mathrm{M} ; \mathrm{HLL}=$ high $\mathrm{Ca}$ and $\mathrm{P}$, low lactose, and low $\mathrm{S} / \mathrm{M} ; \mathrm{LHH}=$ low Ca and $\mathrm{P}$, high lactose, and high $\mathrm{S} / \mathrm{M} ; \mathrm{LHL}=$ low Ca and P, high lactose, and low S/M; LLH = low Ca and P, low lactose, and high S/M; LLL = low Ca and P, low lactose, and low S/M. Data for cheese curds before salting are not shown. 


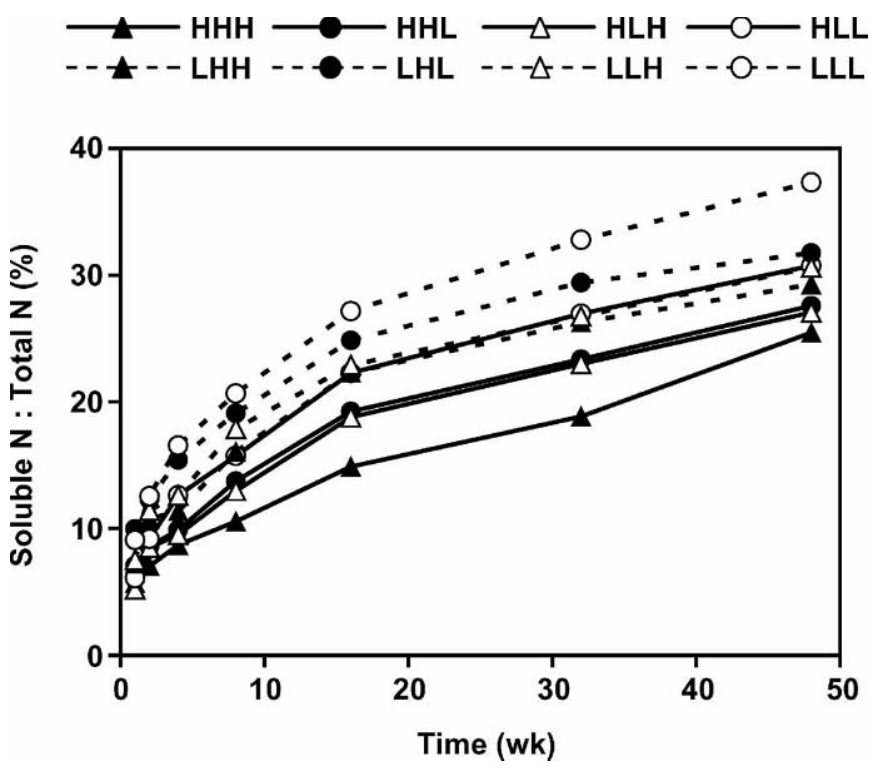

Figure 2. Changes in $\mathrm{pH} 4.6$-soluble $\mathrm{N}$ (as a \% of total $\mathrm{N}$ ) during ripening of the 8 cheeses (mean of 3 replicates). Treatments: $\mathrm{HHH}=$ high $\mathrm{Ca}$ and $\mathrm{P}$, high lactose, and high salt-to-moisture (S/M); HHL = high $\mathrm{Ca}$ and $\mathrm{P}$, high lactose, and low $\mathrm{S} / \mathrm{M} ; \mathrm{HLH}=$ high $\mathrm{Ca}$ and $\mathrm{P}$, low lactose, and high S/M; HLL = high $\mathrm{Ca}$ and $\mathrm{P}$, low lactose, and low $\mathrm{S} / \mathrm{M} ; \mathrm{LHH}=$ low Ca and P, high lactose, and high S/M; LHL = low Ca and $\mathrm{P}$, high lactose, and low $\mathrm{S} / \mathrm{M} ; \mathrm{LLH}=$ low $\mathrm{Ca}$ and $\mathrm{P}$, low lactose, and high S/M; LLL = low Ca and P, low lactose, and low S/M.

end of ripening (Figure 2). This increase was largest in early ripening (until $16 \mathrm{wk}$ ), after which the increase was smaller. The level of $\mathrm{pH} 4.6$-soluble $\mathrm{N}$ is an index of primary proteolysis in cheese. Primary proteolysis is more prominent during the first few weeks of ripening and involves hydrolysis of caseins by residual chymosin, and to a lesser extent by plasmin, resulting in the formation of large and intermediate-sized peptides. Subsequent hydrolysis of these peptides by chymosin and enzymes from the starter and NSLAB results in the formation of smaller peptides and free amino acids during prolonged ripening and does not significantly influence $\mathrm{pH}$ 4.6-soluble $\mathrm{N}$ (Fox and McSweeney, 1996; Sousa et al., 2001). Hence, larger changes in pH 4.6soluble $\mathrm{N}$ are observed during the initial stages of ripening compared with the later stages of ripening.

Effect of $\boldsymbol{C a}$ and $P$. Cheeses with low $\mathrm{Ca}$ and $\mathrm{P}$ had a higher $(P<0.05)$ level of proteolysis than their corresponding high $\mathrm{Ca}$ and $\mathrm{P}$ treatments ( $\mathrm{LHH}$ vs. HHH, LHL vs. HHL, LLH vs. HLH, LLL vs. HLL). In addition, the significant $(P<0.05)$ time $\times \mathrm{Ca}$ and $\mathrm{P}$ interaction indicates that the rate of proteolysis was different in the low $\mathrm{Ca}$ and $\mathrm{P}$ cheeses compared with the high $\mathrm{Ca}$ and $\mathrm{P}$ cheeses (Figure 2). A similar effect of $\mathrm{Ca}$ and $\mathrm{P}$ on proteolysis in cheeses has been observed by other researchers (Marcos et al., 1976; Hsu and Shipe, 1986; Lawrence et al., 1987). The observed differ- ences may be attributed to differences in residual chymosin activity or the state of the para-casein network in low $\mathrm{Ca}$ and $\mathrm{P}$ cheeses. Treatments with low $\mathrm{Ca}$ and $\mathrm{P}$ had a higher level of residual chymosin activity (Table 3) compared with treatments with high $\mathrm{Ca}$ and $\mathrm{P}$. A higher level of chymosin would be expected to increase the rate of proteolysis. In addition, colloidal calcium phosphate acts as a cementing material within casein micelles (Hsu and Shipe, 1986). Depletion of the colloidal calcium phosphates from milk to obtain low $\mathrm{Ca}$ and $\mathrm{P}$ cheeses may also result in a reduction in $\mathrm{Ca}$ and $\mathrm{P}$ crosslinking in the para-casein network of cheese. A reduction in crosslinking may expose a larger surface area of proteins to proteinases and may lead to an increase in enzyme-substrate interactions, and in proteolysis. In addition, differences in moisture content between high and low $\mathrm{Ca}$ and $\mathrm{P}$ cheeses (Table 1) might have a partial influence on proteolysis in cheeses.

In contrast to chymosin, plasmin activity was higher $(P<0.05)$ in the high $\mathrm{Ca}$ and $\mathrm{P}$ treatments than in low $\mathrm{Ca}$ and $\mathrm{P}$ treatments (Table 2). However, the influence of high plasmin activity on proteolysis of high $\mathrm{Ca}$ and $P$ cheeses was not apparent. This can be attributed to the relatively low proteolytic activity of plasmin compared with chymosin in Cheddar cheese. The low plasmin activity in Cheddar cheese is thought to be due to the presence of inhibitors of plasminogen activators in Cheddar cheese. The presence of inhibitors will prevent the conversion of plasminogen to its active form, plasmin, which can cause proteolysis (Bastian and Brown, 1996). This is also supported by the fact that a major fraction of plasminogen in our cheeses still existed as plasminogen, and was not converted to its active form (Table 3).

Effect of Residual Lactose. Cheeses with low lactose exhibited more proteolysis than cheeses with high lactose $(P<0.05)$. In addition, a significant interaction effect of time with lactose $(P<0.05)$ indicates that the rate of change of $\mathrm{pH} 4.6$-soluble $\mathrm{N}$ was different in cheeses with low lactose compared with high lactose (Figure 2). A similar effect of lactose on proteolysis was observed by Shakeel-Ur-Rehman et al. (2004) and Stadhouders (1962). Stadhouders (1962) observed that cheeses that were manufactured by washing the curds for $20 \mathrm{~min}$ had about 1.7 times more rennet than the cheeses that were not washed. The modifications used in our study to manufacture cheeses with different levels of lactose also showed partial influence on residual chymosin activity (Table 2), with low lactose treatments having higher chymosin activity compared with high lactose treatments (Table 2). These differences in residual chymosin might have partially influenced proteolysis in cheeses with high vs. low lactose. However, a complete explanation for differences in proteolysis be- 
tween high vs. low lactose cheeses is not known. These differences in proteolysis can be partially related to differences in moisture between low and high lactose treatments (Table 1).

Effect of $\mathbf{S} / \mathbf{M}$. Cheeses with a low S/M exhibited higher proteolysis compared with cheeses with high S/ $\mathrm{M}(P<0.05)$. In addition, the significance of the interaction effect of time $\times \mathrm{S} / \mathrm{M}(P<0.05)$ indicates that the rate of proteolysis was different in the low $\mathrm{S} / \mathrm{M}$ cheese compared with their high S/M counterparts. A similar influence of $\mathrm{S} / \mathrm{M}$ on proteolysis has been observed by other researchers (Marcos et al., 1976; Thomas and Pearce, 1981; Mistry and Kasperson, 1998; Lane and Fox, 1999).

The differences in proteolysis due to $\mathrm{S} / \mathrm{M}$ can be attributed to changes in protein conformation, or bacterial proteolytic activity. Varying the salt content in cheese influences the ionic strength and may result in conformational changes not only in the enzymes responsible for proteolysis but also in the caseins, which are hydrolyzed (Kristiansen et al., 1999). In aqueous solutions, salt in low concentrations reduced the ability of chymosin to degrade $\beta$-casein, but did not reduce its ability to degrade $\alpha_{\mathrm{S} 1}$-casein (Kristiansen et al., 1999). Similarly, Thomas and Pearce (1981) observed that a change in S/M in Cheddar cheese from 4 to $8 \%$ increased the level of unhydrolyzed $\alpha_{\mathrm{S} 1}$-casein content from 5 to $60 \%$ at 1 mo of ripening at $10^{\circ} \mathrm{C}$, whereas the level of unhydrolyzed $\beta$-casein increased from 50 to $95 \%$. Cheeses with a low S/M also supported a higher population of starter bacteria and exhibited a more rapid increase in NSLAB counts during ripening. This indicates that cheeses with high S/M had lower activity of lactic acid bacteria compared with low S/M cheeses. A lower bacterial proteolytic activity might have contributed to the lower levels of proteolysis in high $\mathrm{S} / \mathrm{M}$ cheeses. Gobbetti et al. (1999) also reported that increasing $\mathrm{NaCl}$ from 2.5 to $7.5 \%$ had a negative effect on the proteinase activity of cetrain lactococcus strains, and attributed it to a decrease in $\mathrm{a}_{\mathrm{w}}$.

\section{CONCLUSIONS}

The present study demonstrates that $\mathrm{Ca}$ and $\mathrm{P}$, residual lactose, and S/M influence overall proteolysis in Cheddar cheese. The differences in proteolysis between treatments were attributed to differences in protein conformation, residual chymosin activity, and lactic acid bacteria activity. Our results verify that changes in set/drain $\mathrm{pH}$ influence the residual chymosin activity in cheeses, which can influence proteolysis. Our experiments also indicate that an increase in set/drain $\mathrm{pH}$ leads to higher plasmin retention. However, a major fraction of plasmin remained in its inactive (plasmino- gen) form, suggesting a minimal role of plasmin in proteolysis in Cheddar cheeses. In our study, the largest change in $\mathrm{pH} 4.6$-soluble $\mathrm{N}$ occurred during the first 16 wk of ripening, after which the increase was small. The observed differences in proteolysis are not only important for Cheddar cheese manufacturers for proper flavor and texture development, but also for process cheese manufacturers, who use natural cheeses as ingredients for process cheeses.

\section{ACKNOWLEDGMENTS}

We thank Dairy Management, Inc. (Rosemont, IL) and Midwest Dairy Association (St. Paul, MN) for funding this project.

\section{REFERENCES}

Bastian, E. D., and R. J. Brown. 1996. Plasmin in milk and dairy products: An update. Int. Dairy J. 6:435-457.

Broadbent, J. R., K. Houck, M. E. Johnson, and C. J. Oberg. 2003. Influence of adjunct use and cheese microenvironment on nonstarter bacteria in reduced-fat Cheddar-type cheese. J. Dairy Sci. 86:2773-2782.

Bynum, D. G., and D. M. Barbano. 1985. Whole milk reverse osmosis retentates or Cheddar cheese manufacture: Chemical changes during aging. J. Dairy Sci. 68:1-10.

Crow, V., B. Curry, and M. Hayes. 2001. The ecology of non-starter lactic acid bacteria (NSLAB) and their use as adjuncts in New Zealand Cheddar. Int. Dairy J. 11:275-283.

Dawson, D. J., and J. T. Feagan. 1957. Bacteriology of Cheddar cheese: A study of starter organisms in manufacture and maturing. J. Dairy Res. 24:210-224.

Fajardo-Lira, C., M. Oria, K. D. Hayes, and S. S. Nielsen. 2000. Effect of psychrotrophic bacteria and of an isolated protease from Pseudomonas fluorescens M3/6 on the plasmin system of fresh milk. J. Dairy Sci. 83:2190-2199.

Farkye, N. Y., and P. F. Fox. 1990. Observations on plasmin activity in cheese. J. Dairy Res. 57:413-418.

Fox, P. F., and P. L. H. McSweeney. 1996. Proteolysis in cheese during ripening. Food Rev. Int. 12:457-509.

Gobbetti, M., R. Lanciotti, M. D. Angelis, M. R. Corbo, R. Massini, and P. Fox. 1999. Study of the effects of temperature, $\mathrm{pH}, \mathrm{NaCl}$, and $\mathrm{a}_{\mathrm{w}}$ on the proteolytic and lipolytic activities of cheese-related lactic acid bacteria by quadratic response surface methodology. Enzyme Microb. Technol. 25:795-809.

Grufferty, M. B., and P. F. Fox. 1988. Factors affecting the release of plasmin activity from casein micelles. N.Z. J. Dairy Sci. Technol. 23:153-164.

Holmes, D. G., J. W. Duersch, and C. A. Ernstrom. 1977. Distribution of milk clotting enzymes between curd and whey and their survival during Cheddar cheese making. J. Dairy Sci. 60:862-869.

Hsu, H. Y., and W. F. Shipe. 1986. Effects of some chemical and physical treatments on proteolysis in milk. J. Dairy Sci. 69:1491-1497.

Hurley, M. J., B. M. O'Driscoll, A. L. Kelly, and P. L. H. McSweeney. 1999. Novel assay for the determination of residual coagulant activity in cheese. Int. Dairy J. 9:553-568.

Kristiansen, K. R., A. S. Deding, D. F. Jensen, Y. Ard, and K. B. Qvist. 1999. Influence of salt content on ripening of semi-hard round-eyed cheese of Danbo-type. Milchwissenschaft 54:19-23.

Lane, C. N., and P. F. Fox. 1999. The individual or combined action of chymosin and plasmin on sodium caseinate or $\beta$-casein in solution: Effect of $\mathrm{NaCl}$ and $\mathrm{pH}$. Lait 79:423-434.

Lawrence, R. C., L. K. Creamer, and J. Gilles. 1987. Texture development during cheese ripening. J. Dairy Sci. 70:1748-1760. 
Lehtola, P., and L. E. Metzger. 2004. A comparison of three different methods for measuring intact casein in cheese. J. Dairy Sci. 87(Suppl. 1):285. (Abstr.)

Marcos, A., M. Alcalá, F. León, J. Fernández-Salguero, and M. A. Esteban. 1981. Water activity and chemical composition of cheese. J. Dairy Sci. 64:622-626.

Marcos, A., M. A. Esteban, and J. Fernández-Salguero. 1976. Influence of some chemical and physical factors on the proteolysis of cheese caseins. Arch. Zootec. 25:73-86.

Mistry, V. V., and K. M. Kasperson. 1998. Influence of salt on the quality of reduced fat Cheddar cheese. J. Dairy Sci. 81:1214-1221.

Nelson, B. K. 2005. Composition and dynamics of the water phase of Cheddar cheese. Ph.D. Thesis, Cornell University, Ithaca, NY.

Peichevski, I., and N. Petrova. 1979. Effect of lactose content on biochemical processes during ripening of Vitosha cheese. Nauchni Trudove. Vissh Institut po Zootekhnika i Veterinarna Meditsina 26:221-229.

Roy, D. 1991. Salt stress on growth and acid production of Lactobacillus helveticus strain milano. Lett. Appl. Microbiol. 12:207-211.

Sandine, W. E., P. C. Radich, and P. R. Elliker. 1972. Ecology of the lactic streptococci. A review. J. Milk Food Technol. 35:176-185.

SAS lnstitute. 1990. SAS User's Guide: Statistics, Version 6.0 ed. SAS lnst. Inc., Cary, NC.
Schroeder, C. L., F. W. Bodyfelt, C. J. Wyatt, and M. R. McDaniel. 1988. Reduction of sodium chloride in Cheddar cheese: Effect on sensory, microbiological, and chemical properties. J. Dairy Sci. 71:2010-2020.

Shakeel-Ur-Rehman, D. Waldron, and P. A. Fox. 2004. Effect of modifying lactose concentration in cheese curd on proteolysis and in quality of Cheddar cheese. Int. Dairy J. 14:591-597.

Sousa, M. J., Y. Ardö, and P. L. H. McSweeney. 2001. Advances in the study of proteolysis during cheese ripening. Int. Dairy J. 11:327-345.

Stadhouders, J. 1962. The proteolytic activity of rennet and starter bacteria in cheese with reference to bitter flavour. Pages 353361in XVI Int. Dairy Congress, volume B, Copenhagen, Denmark.

Thomas, T. D., and K. N. Pearce. 1981. Influence of salt on lactose fermentation and proteolysis in Cheddar cheese. N.Z. J. Dairy Sci. Technol. 16:253-259.

Upreti, P., and L. E. Metzger. 2006. Influence of calcium and phosphorus, lactose, and salt-to-moisture ratio on Cheddar cheese quality: Manufacture and composition. J. Dairy Sci. 89:420-428.

Wiles, P. G., I. K. Gray, and R. C. Kissling. 1998. Routine analysis of proteins by Kjeldahl and Dumas Methods: Review and interlaboratory study using dairy products. J. AOAC Int. 81:620-632. 